\title{
SERIOUS GAMES IN MILITARY APPLICATIONS
}

\author{
Andreja B. Samčović
}

University of Belgrade, Faculty for Transport and Traffic Engineering, Belgrade, Republic of Serbia, e-mail: andrej@sf.bg.ac.rs,

(10)ORCID iD: http://orcid.org/0000-0001-6432-2816

DOI: 10.5937/vojtehg66-16367; https://doi.org/10.5937/vojtehg66-16367

FIELD: Computer Science, Telecommunications, Informatics

ARTICLE TYPE: Review Paper

ARTICLE LANGUAGE: English

\section{Summary:}

Serious games as one of the most important trends in e-learning are presented in this paper. An intensive use of information and communication technologies has led to major changes in traditional military education. One of these changes is the use of serious games for simulating the real military environment. This review paper presents several definitions and classifications of serious games, the difference between serious and entertainment games, and considers their military applications in training and simulation systems as well as in education.

Key words: serious games, video games, military education, simulation.

\section{Introduction}

There have been an increasing number of serious games in the last ten years that are related to a wide range of different areas: health, military, education, communication, etc (Djaouti et al, 2011).

The first formal definition of the concept of serious games was launched by Abt in his book (1987), which presents simulations and games for the promotion of education, both inside and outside the classroom. He provided the examples either a "mainframe computer" or games based on the "pen and paper" concept, when the video game industry had not yet started. Jansiewicz (1973) published a book describing the game he invented to learn the basics of American politics.

Years later, the concept of a "serious game" was redefined in the work written by Sawyer (2009). Several definitions of serious games have been proposed in the last decade by various authors and organizations:

ACKNOWLEDGMENT: This paper is partially supported by the Ministry of Education, Science and Technological Development of the Republic of Serbia (Project No. 32025). 
Zyda (2005) defined the serious game as "A cerebral challenge, played with a computer according to specific rules, which uses entertainment as an added value for training in institutional or private environments in the fields of education, health, civil security, as well as for communication strategy purposes".

Chen and Michael (2005) defined serious games as "games that have no fun or enjoyment as their primary goal". The term "seriousness" of these games refers to content that can be well used in education as a teaching material by a lecturer.

Alvarez \& Michaud (2008) specified serious games as "Computer application, the aim of which is to combine at the same time serious aspects such as, but not limited to, teaching, learning, communication, or information, with ludic springs coming from the video game". Such an association, which takes place through the implementation of a "pedagogical scenario", is therefore aimed at moving away from entertainment.

Serious games can also be used to learn media literacy, showing that video games are not just "neutral" and can include "serious" content (Matteas, 2008). Sawyer \& Reyeski helped the industry to form "Serious Games Initiative" and organized conferences such as "Serious Games Summit" and "Games for Health" (Games for Health Conference, 2008). A wider definition of "serious games" includes any software that connects non-entertainment purpose (serious) to the structure of the video game. Designers of serious games use interest in video games to capture the attention of users for various purposes that go beyond pure entertainment.

Center for resources and information on multimedia for higher education has the following definition: "A real training tool, communication, simulation, the serious game is a sort of useful declination of the video game at the service of the professionals. Serious games are applications developed from advanced video game technologies, using the same design and know how approaches as the classic game (3D real time, simulation of objects, individuals, environments...) but which go beyond the sole dimension of entertainment".

From these various definitions, we can conclude that the serious game is a game that combines a serious intention with playful springs of video games. So we take a video game and we associate a utility function with it. The serious game must have three utility functions: disseminate a message, provide training and allow data collection. 
After the introduction, the second part considers some applications of serious games. The difference between serious and entertainment games is presented in the next section. The paper continues with the description of the simulation training in military systems. The core components of serious games are also presented because of their importance. Some examples of an application of serious games in the military edutainment are shown in the last section. Finally, at the end of the paper, concluding remarks are mentioned.

\section{Classification of serious games}

Serious games mean different names, e.g. "immersive learning simulation", "digital game-based learning", "gaming simulations", and "games that you have to play". Serious games are related to games designed to improve learning, whereas application fields include military training, health care, different levels of education, and many other social purposes. Serious games are not primarily designed for fun purpose. They have an organized game situation and have the meaning and purpose to play. The purpose of serious games in military applications is to prepare for real life situations. These games are played with the purpose of being able to cope with extreme and dangerous situations which players could face. Marczewski (2013) described military serious games as a simulator system, games that are safe for practice and perform as a virtual presentation of a real life situation.

The term serious game (SG) originates from (Abt, 1987) and is applied for games that are not developed exclusively for entertainment, but primarily for the creation of an educational value. SGs are counted among current e-learning trends and gain more and more acceptance and influence (Doujak, 2015). The development of SGs is different from entertainment games. SGs are usually individual products for a limited target audience, or organizations, such as military. This leads to high costs, although the market is showing increasing interest in economical and customized applications (Doujak, 2015). Alvarez \& Michaud (2008) classified serious games in five categories, as presented in Figure 1. Possible military applications include edutainment games and training and simulation games. 


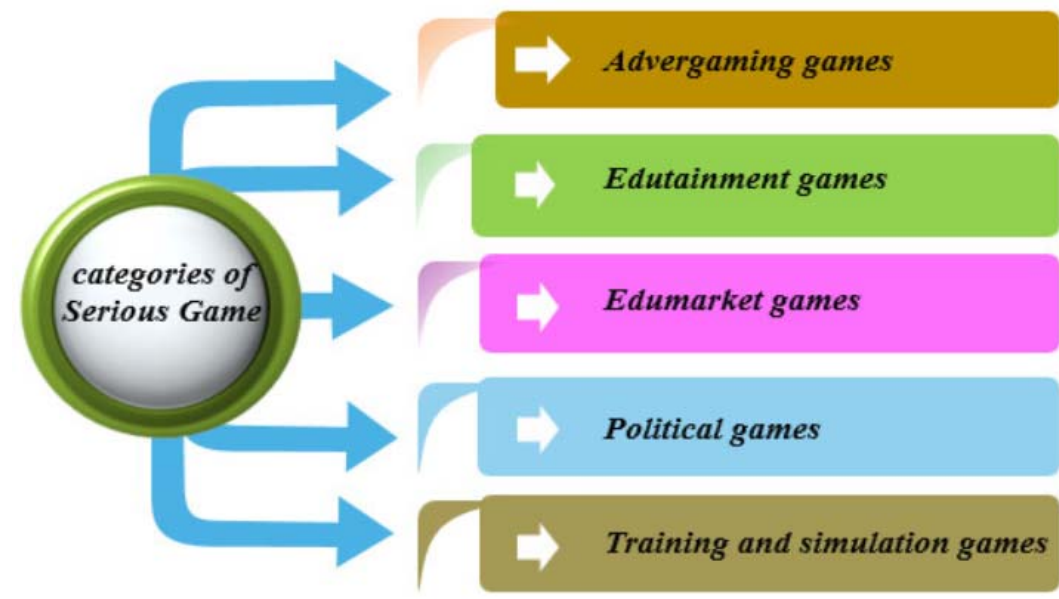

Figure 1 - Classification of serious games (Alvarez \& Michaud, 2008) Puc. 1 - Классификация серьезных игр (Alvarez \& Michaud, 2008) Слика 1 - Подела озбиљних игара (Alvarez \& Michaud, 2008)

Pringle (2007) investigated the use of game technology in military applications. He suggested that serious games could be useful in military training. The military training would have benefits if games combine different technologies. Roman \& Brown (2008) concluded that there are few well-defined standards for the measurement efficiency of SGs. Only several military organizations have launched the necessary studies until now to include serious games in military applications.

The most remarkable example of the military application of serious games is America's Army. This serios game is designed for the recruitment process and education of youth about the military lifestyle (America's Army, 2010). That game pointed out an excitement in the military life.

\section{Serious games and entertainment games}

There is a big difference between those games with "moving purpose" and the games designed by the serious games industry. The first group includes video games that were not originally designed to serve for serious purposes, but exclusively for entertainment. However, when instructors use fun games for teaching that have a "serious scenario", the purpose of video games moves to serious ones. This "serious" dimension is not directly embedded in the game, but the 
instructor uses it in a way that his students can play the game for educational purposes. So, we can consider that it is a matter of both "serious" and "game". The instructors are then obligated to adhere to a pre-prepared scenario and adapt it to their "serious" goals, while designers have full control over the contents of their games. The relationship between serious game, video game and serious gaming is illustrated in Figure 2.

There are serious games designed as software modifications for entertainment video games on the halfway between "moving purpose" and games designed from the very beginning to serve as serious games. For example, the game Escape from Woomera (Valentine \& Jensen, 2016 ) is a software modification of the Half-Life video game. The HalfLife game, originally related to the fight against an alien invasion, has been transformed into "serious" information on the difficult living conditions at Australian refugee centers.

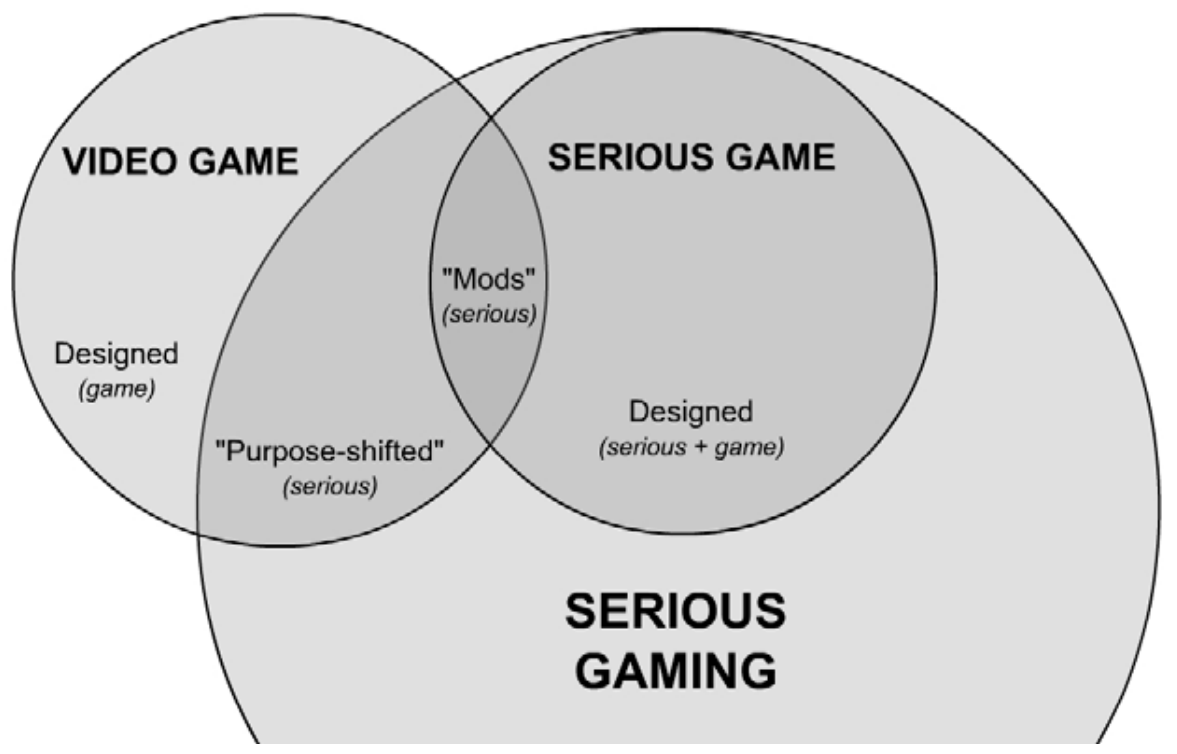

Figure 2 - Relationship between serious game, video game and serious gaming (Djaouti et al, 2011)

Рис. 2 - Взаимосвязь между серьезными играми, видеоиграми и серьезной игрой (Djaouti et al, 2011)

Слика 2 - Однос између озбиљне игре, видео-игре и озбиљног играња (Djaouti et al, 2011)

The appropriate software must be designed for both dimensions: "serious" and "game" in order the "serious game" to be considered as 
relevant. Video games today have a very constructive role in educating people of all ages in educational institutions, workplaces and homes, around the world. Video games can also be significant in learning technical skills (Žižović \& Plećić, 2017).

Games can play an important role at universities, as a way to increase students' efficiency to learn education materials faster and in a much better way. Universities can use video game for training in technical fields such as aerospace, electrical and computer engineering. While the participants play the game, they use their skills to learn the game and do it better every time they play. During the game, students learn the technical aspects of objects, which can be used in the real world (El Azizi \& Arbai, 2017). Games have changed completely the way of life of the youngest generation. Online games such as Monopoly and Sudoku have not only increased their analytical skills, but also their ability to cope with various situations such as panic, stress, and relationships with peers.

The ability to manage multiple tasks and resources is one of the goals that help video game participants. Learning the rules and strategy of the game also helps the participants of the games. Video games encourage students to play together in the team. A fun way of games helps participants to keep pace with technology changes, thereby increasing their confidence. Video games can help to gain selfconfidence by helping them to understand different emotions. Some people think that games make students be withdrawn and asocial, but there are studies pointing to the opposite. Most students like to play video games in pairs or in small groups. That play stimulates competition and strengthens the strategy.

Video games are not just tools for entertainment and relaxation, they create an atmosphere of learning and experience. Students and adults develop the key skills needed for the world through navigation an animated computer screen. To increase initiatives for serious games, various media must be able to work efficiently with current web 2.0 technology (Jaume-i-Capo \& Samčović, 2015). In principle, software and hardware must be able to handle such games.

\section{Simulation training and games in military systems}

When employed for military applications, serious games are used to train soldiers using virtual environments that reproduce real-world scenarios. The main scope is to prepare soldiers for the situations and 
obstacles that may appear in the real world, to make them able to take decisions faster and safer.

War games are analytic games that simulate aspects of warfare at the tactical, operational, and strategic levels. They are used to examine war fighting concepts, train and educate commanders and analysts, explore scenarios, and assess how force planning and posture choices affect campaign outcomes. War games combine game, experiment and performance. They simulate a military operation involving two or more opposing forces, using rules, data, and procedures designed to depict an actual or assumed real life situation.

Military simulations are simulations in which theories of warfare can be tested and refined without the need for actual hostilities. The main difference between military simulations and war games is generally taken the last to be referring to the civilian hobby, thus the preference for the term simulation. Military simulations are seen as a useful way to develop tactical, strategic and doctrinal solutions, but critics argue that the conclusions drawn from such models are inherently flawed, due to the approximate nature of the models used.

From a military perspective, serious game playing has a number of advantages, such as improved hand-eye coordination, improved ability to multitask, ability to work in a team using minimal communication, and willingness to take aggressive action (Chen \& Michael, 2005). Many previous military simulations and war games have concerned combat, but more recent efforts also concern skills such as foreign languages and cultural training. Future application areas for the military field include massively multiplayer online games and virtual reality trainers.

We will present in this section some information about the type of modern military operations. During the Cold War, military operations were focused on big battle operations on a particular battlefield where all participants were expected to be fighters (Smith 2008a). In the modern time, the focus was usually on small unit operations in urban areas where military units are called to operate in humanitarian operations, to search, to defense objects, or to combat operations. Hence, virtual environments must represent different objects and interactions, as well as high amount of detail in the field of operations (Smith, 2008a). The virtual environments should also be capable of allowing person-to person communication that would make possible the knowledge that can be useful in military missions. This requires research in group models and personal relationships from social, cultural, and geographical points of view. Virtual environments that are able to accurately represent such 
diversity could effectively be an important challenge and a significant point in military applications (Smith, 2008a).

Having in mind the above described characteristics of modern military operations, dynamic modeling of military systems and missions points on the activities are described in (Smith, 2007). The relationships among these activities are presented in Figure 3.

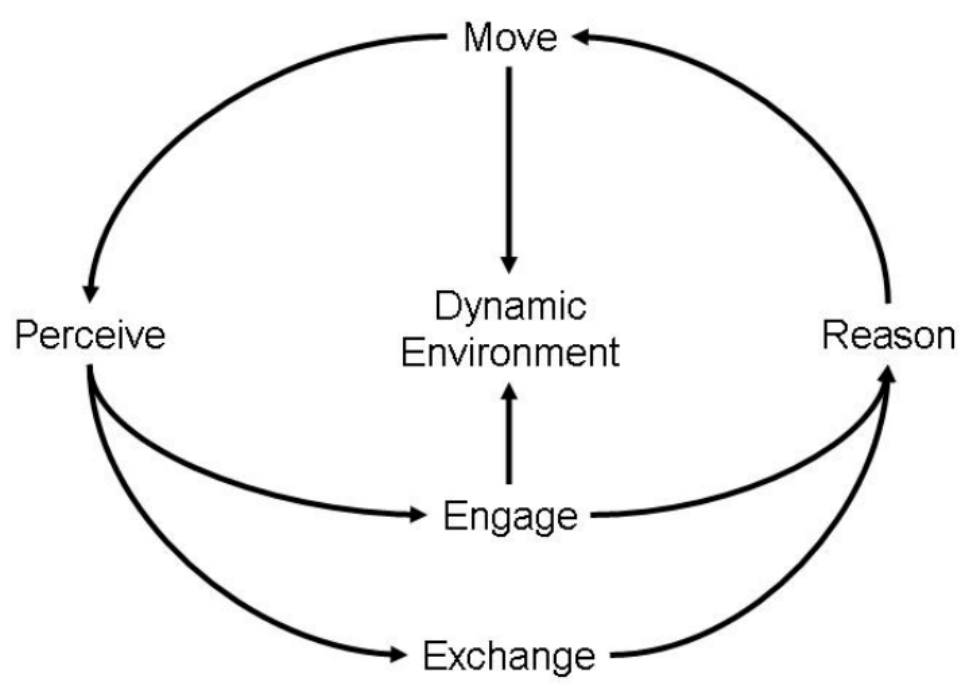

Figure 3 - Relationship model for a simple battlefield simulation (Smith, 2007)

Puc. 3 - Простое моделирование поля боя (Smith, 2007)

Слика 3 - Модел за једноставну симулацију бојног поља (Smith, 2007)

Move: Dynamic representation of a move includes a change in the position of the object over time.

Perceive: Military objects trigger the environment in order to communicate with other objects. The first step in this interaction is to perceive or discover the existence, position and identification of another object.

Exchange: Models are needed to allow objects to exchange materials and information with each other, after move and detection. Battlefield operations usually lead to the exhaustion of materials such as fuel, ammunition, food, medical devices, vehicles and people. Logistics model can be used to represent the army abilities to continuously deliver these materials to units and facilities during the military operation.

Engage: The engagement model typically involves exchange of weapons or firearms from the shooter to the target. This exchange 
reduces capability of the shooter by expanding ammunition in one of many shapes (e.g. bullets, missiles, bombs, rockets, artillery).

Reason: Reasoning models rely usually on techniques developed in the field of artificial intelligence. Techniques such as expert systems, rule-based systems, neural networks, fuzzy logic, finite state machines, case-based reasoning, final analysis, and others organize information and form decisions that are similar to those of living beings.

Dynamic environment: There has been an evolution of a simulated environment from static structures to dynamic characteristics and their interactions with military facilities.

\section{Components of game technologies}

Commercial video games include technologies that have value for industries outside the environment, including military simulations. The technical cores of the game technology which military industry can use are the following (Smith, 2008b):

- 3D engine - presenting the simulated world by creation of the attractive and accurate visualizations that are used to stimulate players;

- Graphical user interface (GUI) - easy access and control the game system, it is the menu system and interactive patterns that allow a gamer to immediately begin using a game without ever reading a manual;

- Artificial intelligence (Al) - provides the brains that are necessary to create in-game components that are smart enough to challenge human players. This also creates an adaptive experience that can adjust the game as it runs to insure that the player works through a specific problem of interest;

- Physical models - create the world which includes movement, communication, detection, engagement interactions, and sensors that are accurate portrayals of the real world;

- Global networking - connecting on demand among players; it allows the virtual environment to be extended to multiple players around the globe. Game companies have created the most flexible and efficient methods for transferring data over a worldwide network;

- Persistent worlds - larger context for a small unit mission. It is also a 3D portal for tactics and intelligence data. They maintain a virtual world that can grow, change and remain active over many days, weeks, or years regardless of whether an individual player remains engaged with that world.

The above mentioned six core technologies for serious games are illustrated in Figure 4. 


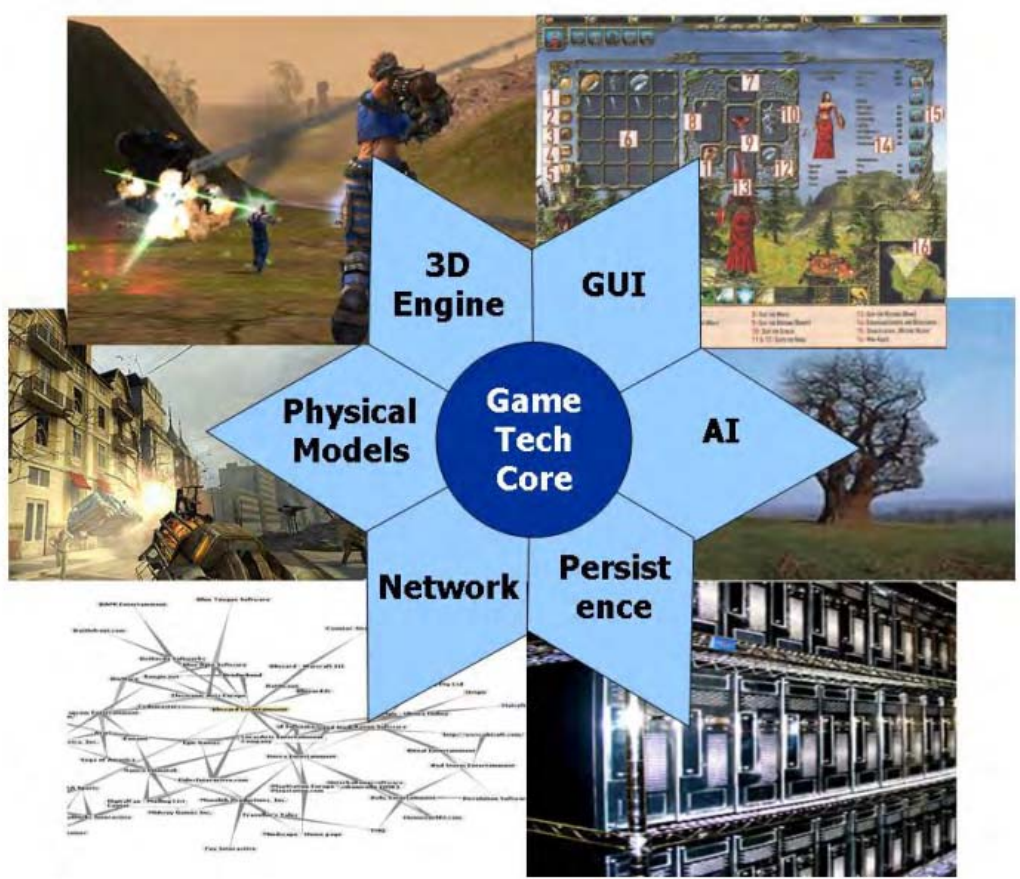

Figure 4-Key technologies for serious games (Smith, 2008b) Puc. 4 - Ключевые технологии для серьезных игр (Smith, 2008b)

Слика 4 - Кључне технологије код озбиљних игара (Smith, 2008b)

There is still not much overlapping between military simulations and game technology as Figure 5 shows. Military simulations focus on providing information, terrain data, networking, interoperability standards, facilities, etc. Game technology, on the other hand, focuses on 3D development, artificial intelligence, physical models, multiplayer games, etc.

A possible framework based on military simulations, game technology and the use of modern technology in military training, will be described. The framework will provide the following aspects of military practice (Yildirim, 2010):

- Training of military staff for specific cases. The case is a scenario that includes location (unknown objects, maps), people (how they look, how they dress), time (how many hours there are, effects of the time on the environment, how the operations can be carried out differently in different hours);

- Creating a list of cases and designing interactions and dependencies between cases; 
- Creating a list of tactics within a context for each possibility;

- Monitoring the environment in real time by military equipment and transmission information obtained in the game. Moreover, the location specifications, people, weather, etc. can be monitored;

- The soldiers are dressed to blend in the environment around them, e.g. they wear camouflage clothes such as white uniforms in the snow conditions;

- Basic activities of military simulation systems, like movement, perception, exchange, engagement, dynamic environment, which is presented in Figure 6;

- The main components of game technologies: 3D engine, graphical user interface, artificial intelligence, physical models, networking;

- Enabling the possibility of running tactics and strategies of military operations;

- Social aspects of the operation environment;

- Developing an easy-to-understand user access.

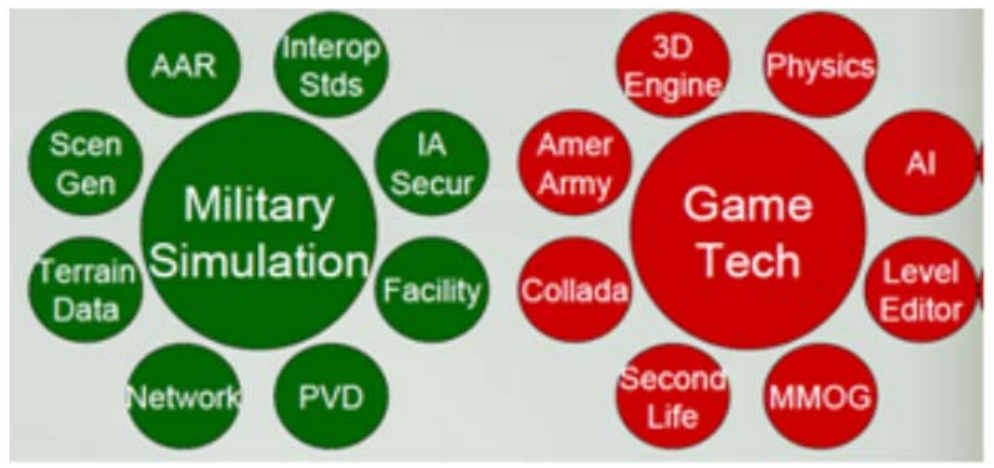

Figure 5 - Military simulation vs. game technology (Smith, 2008b)

Puc. 5 - Взаимосвязь между военным моделированием и технологией игр (Smith, 2008b)

Слика 5 - Веза између војне симулације и технологије игара (Smith, 2008b)

The described framework indicates a serious game for military training. That framework combines military simulation systems, key aspects of game technology, as well as social and cultural aspects of military operations, which is shown in Figure 5. CBR means case based reasoning. 


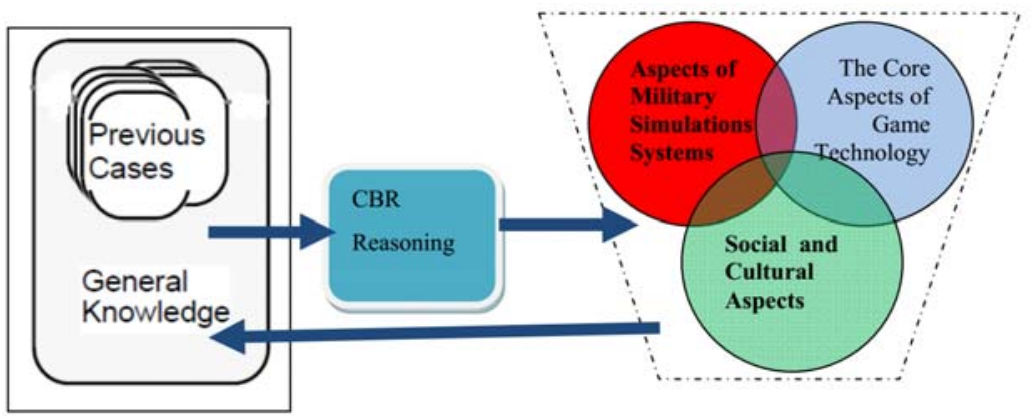

Figure 6 - Acivities in military simulation systems (Yildirim, 2010)

Puc. 6 - Активности в рамках военного моделирования (Yildirim, 2010)

Слика 6 - Активности у оквиру система војне симулације (Yildirim, 2010)

\section{Edutainment games in military systems}

Serious games are oriented to teaching and training, simulating everyday situations, or some specific activities. Serious games can consist of professional development for people who perform specific tasks of their personal activities, people's awareness about a particular topic, or everyday situations, such as vehicle configuration. Through this kind of game, simulations should be attractive and playful, while offering activities that favor the assimilation of practices and psychomotor abilities. Therefore, serious games mean digital applications that exceed the entertainment and we can say that their main goal is learning and practicing specific situations, such as, for example, military applications.

Serious games are suitable for military training by simulation of critical situations, including risk, decision making, or to develop specific activities. Other application of serious games involves military teaching where some real situations can be simulated. The knowledge of a player is essential to the evolution of a serious game. One of the objectives of serious games is to develop the stimulation of the cognitive functions, the motivation and knowledge acquisition of the players.

The first fighting video simulation was designed by Mak Industries, (Cruz-Cunha, 2012). This simulator was realized on the request of the US Marine Corps in 1997. In 1998 US Army, together with the industry, entered into a contract to continue the development of the video game Spearhead, to be used in the US Army Center and School for Training Purposes. At the beginning, these video games were designed only for military use.

The US Army presented in 2003 a new video game for the recruitment, which got the name America's Army (2010). This game had 
a great success. That game was considered to be the first serious game with military application. The details provided the closest sense of being a part of a fight. This game had the influence on its users by bridging virtual experience with real or simulated (air and paintball games) fight experience. One example of the simulation of military activities is shown in Figure 7.

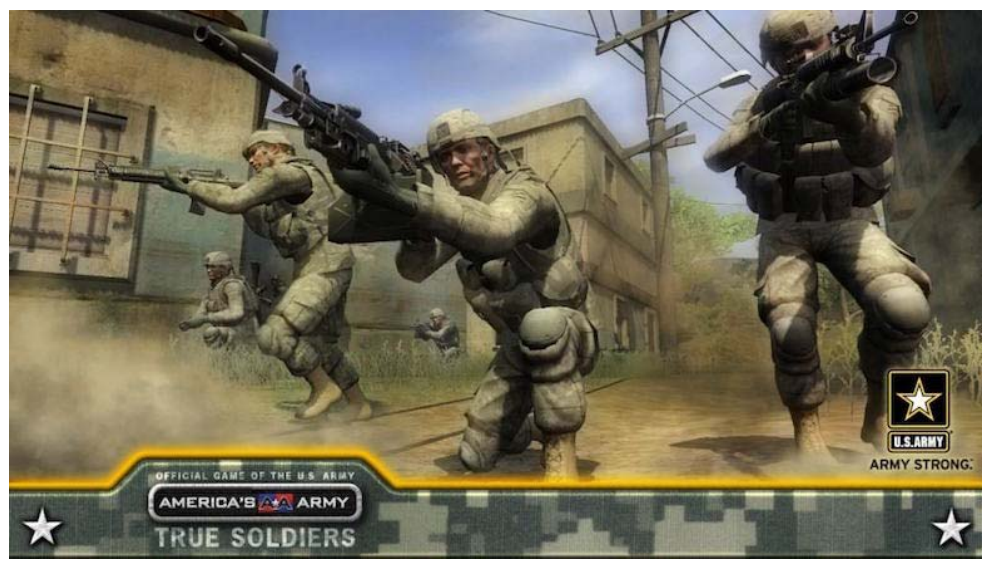

Figure 7 - Acivities in military simulation systems (America's Army, 2010)

Puс. 7- Активности в рамках военного моделирования (America's Army, 2010) Слика 7 - Активности у оквиру система војне симулације (America's Army, 2010)

SanTrain is an example of a serious game designed in the field of military first aid (Dobrovsky et al, 2017). It provides a game-based learning approach and a platform for training tactical combat casualty care. It means a specialized first aid on a battlefield and includes simple life saving steps and priorities for the first minute after injuries. The objectives of this serious game are to prioritize and treat injuries that could endanger life, to prevent further injuries and to complete a military mission. The basic principles come from the US special operations forces experience in real fighting scenarios. It has been shown that, through prioritized treatment at the battlefield, lives of soldiers with lifeendangering injuries can be saved. This training can be practiced in the armed forces not only by medical personnel, but also by regular soldiers. The screen-shot of the SG SanTrain is presented in Figure 8. 


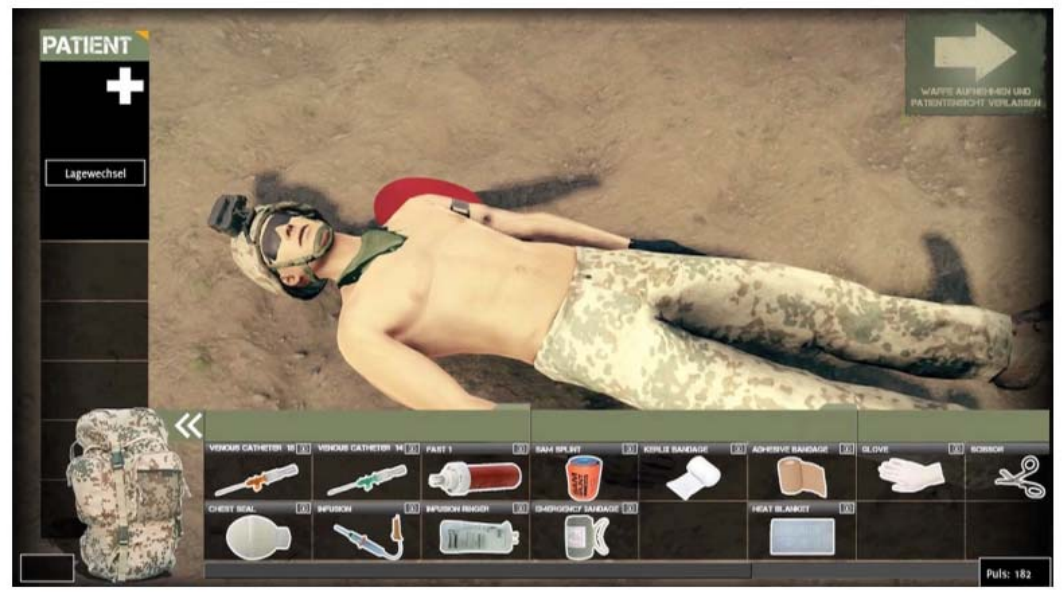

Figure 8 - Screen-shot of the SanTrain game (Dobrovsky et al, 2017)

Puc. 8 - Изображение из игры SanTrain (Dobrovsky et al, 2017)

Слика 8 - Приказ у оквиру игре SanTrain (Dobrovsky et al, 2017)

Another example of a serious game designed for training military medical stuff and nonmedical soldiers with training on providing lifesaving care is TC3Sim (Hussain \& Coleman, 2014). The game tasks are considered with tactical combat casualty care, including care under fire, which is illustrated in Figure 9 showing a screen-shot of this game. The training system, as well as the used scenarios, have been publicly available in an effort to promote further study on this project.

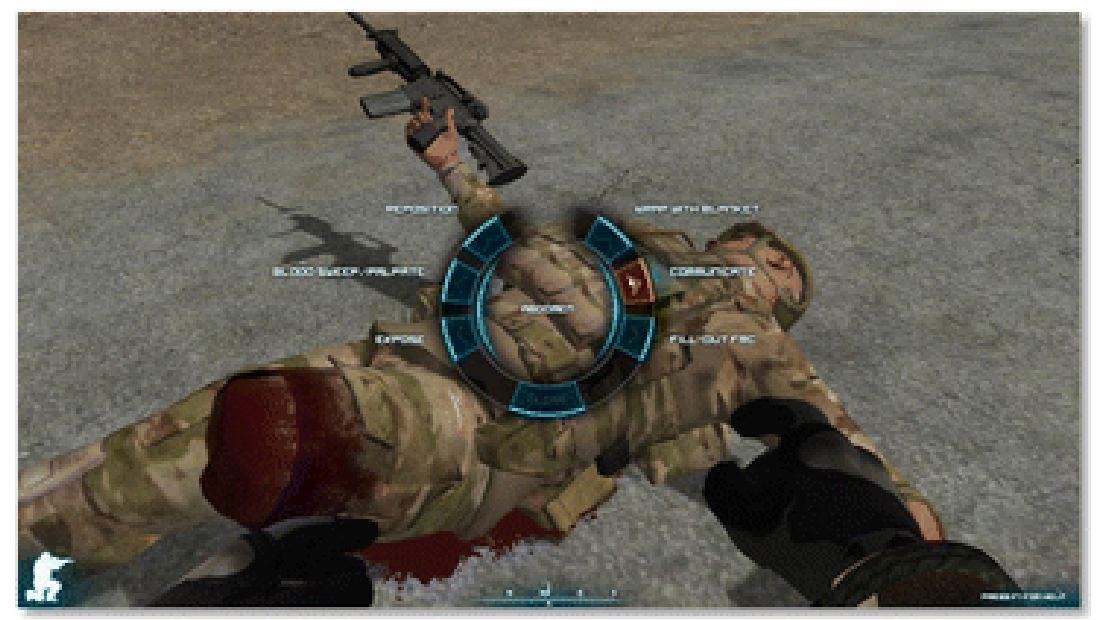

Figure 9 - Screen-shot of the TC3Sim game (Hussein and Coleman, 2015) Puc. 9 - Изображение из игры TC3Sim (Hussein and Coleman, 2015) Слика 9 - Приказ у оквиру игре TC3Sim (Hussein and Coleman, 2015) 


\section{Conclusion}

Serious games are now being gradually involved into numerous applications such as military applications. Serious games in military have impact on education, training and learning of military staff. The concept of military games can improve the user's motivation. Several studies have demonstrated that serious games help to motivate users in the training. The realism required in military simulations can be achieved by game technologies. More recent studies show the benefits of using computer vision as an input mechanism. It can be concluded that serious games come from video games, but with a "serious scenario". On the other hand, the psychological and social aspects of serious games should be investigated and taken into account.

\section{References}

Abt, C.C. 1987. Serious games. University Press of America.

Alvarez, J., \& Michaud, L. 2008. Serious Games: Advergaming, edugaming, training and more. IDATE.

America's Army. 2010. Available at: http://www.americasarmy.com. Accessed: 22.01.2018.

Chen, S., \& Michael, D. 2005. Serious Games: Games that Educate, Train and Inform. Thomson Course Technology.

Cruz-Cunha, M.M. 2012. Handbook of Research on Serious Games as Educational, Business and Research Tools. IGI Global. Available at: https://doi.org/10.4018/978-1-46660-149-9.

Djaouti, D., Alvarez, J., \& Jessel, J. 2011. Classifying serious games: the G/P/S model. In: R. Tennyson \& P. Felicia Eds., Handbook of Research on Improving Learning and Motivation Trough Educational Games: Multidisciplinary Approaches. IGI Global, pp.118-136. Available at: https://doi.org/10.4018/978-160960-495-0.ch006.

Dobrovsky, A., Borghoff, U.M., \& Hofmann, M. 2017. Applying and Augmenting Deep Reinforcement Learning in Serious Games through Interaction. Periodica Polytechnica Electrical Engineering and Computer Science, 61(2), p.198. Available at: https://doi.org/10.3311/ppee.10313.

Doujak, G. 2015. Serious games and digital game based learning, Spielebasierte E-Learning Trends der Zukunft. GRIN Verlag.

El Azizi, L., \& Arbai, A. 2017. Serious Games for the Development of Learning. Transactions on Machine Learning and Artificial Intelligence, 5(4). Available at: https://doi.org/10.14738/tmlai.54.3216.

Games for Health Conference. 2008. Baltimore, USA.

Hussain, T.S., \& Coleman, S.L. 2014. Design and Development of Training Games. Cambridge: Cambridge University Press, pp.1-5. Available at: https://doi.org/10.1017/cbo9781107280137.001. 
Jansiewicz, D. 1973. The New Alexandria simulation: A serious game of state and local politics. Canfield Press.

Jaume-I-Capó, A., \& Samčović, A. 2015. Interactive multimedia system using serious game for users with motor disabilities. Telfor Journal, 7(2), pp.97102. Available at: https://doi.org/10.5937/telfor1502097j.

Marczewski, A. 2013. Gamification: A simple introduction.

Matteas, M. 2008. Procedural Literacy: Educating the New Media Practitioner. In: D. Davidson Ed., Beyond Fun: Serious Games and Media. ETC Press.

Pringle, R. 2007. Gaming technology impacting military training. Military Training Technology, 12(6).

Roman, P.A., \& Brown, D. 2008. Games-just how serious are they. In: The interservice/industry training, simulation \& education conference (I/ITSEC), 2008(1).

Sawyer, B. 2009. Serious Games: Improving Public Policy through Gamebased Learning and Simulation. Woodrow Wilson International Center for Scholars.

Smith, R. 2007. Military modeling, Handbook of dynamic systems modeling. CRC Press.

Smith, R. 2008a. The future of virtual environment training in the army. In Handbook of virtual environment training in the army. Greenwood Publishing Group.

Smith, R. 2008b. New Technology for M\&S: Web 2.0. In IT Services, HPC, Games, OSD/ROK Defense M\&S Workshop. Korean Institute for Defense Analyses.

Yildirim, S. 2010. Serious game design for military training. In Games: Design and Research Conference. Volda University College.

Valentine, K.D., \& Jensen, L.J. 2016. Examining the Evolution of Gaming and Its Impact on Social, Cultural, and Political Perspectives. Hershey, PA: IGI Global. Available at: https://doi.org/10.4018/978-1-5225-0261-6.

Zyda, M. 2005. From visual simulation to virtual reality to games. Computer, 38(9), pp.25-32. Available at: https://doi.org/10.1109/mc.2005.297.

Žižović, M., \& Plećić, K. 2017. Muticriteria assessment of possible use of computer games in teaching. Vojnotehnički glasnik / Military Technical Courier, 65(3), pp.641-650. Available at: https://doi.org/10.5937/vojtehg65-13000.

СЕРЬЕЗНЫЕ ИГРЫ В ВОЕННОЙ ПОДГОТОВКЕ

Андрея Б. Самчович

Белградский университет, Факультет транспорта и путей сообщения,

г. Белград, Республика Сербия

ОБЛАСТЬ: компьютерные науки, телекоммуникации, информатика ВИД СТАТЬИ: обзорная статья ЯЗЫК СТАТЬИ: английский

Резюме:

Серьезные игры на сегодняшний день представляют самый популярный тренд в системе электронного образования. Маситабное использование информационных и коммуникационных технологий привело к крупным переменам в традиционном военном образовании. Одна из таких перемен отражается в 
использовании серьезных игр при моделировании реальных боевых действий. В данной обзорной статье представлены несколько определений, классификаций серьезных игр и объясняется разница между серьезными играми и играми для развлечения. Кроме того, в работе рассматриваются военные приложения, пригодные $в$ учениях, системе моделирования и в военной подготовке.

Ключевые слова: серьезные игры, видео игры, военная подготовка, моделирование.

ОЗБИЉНЕ ИГРЕ У ВОЈНОЈ ПРИМЕНИ

Андреја Б. Самчовић

Универзитет у Београду, Саобраћајни фракултет,

Београд, Република Србија

ОБЛАСТ: рачунарске науке, телекомуникације, информатика

ВРСТА ЧЛАНКА: прегледни чланак

ЈЕЗИК ЧЛАНКА: енглескИ

Сажетак:

Озбиљне игре представљају један од најзначајнијих трендова у електронском образовању. Интензивно коришћење информационих и комуникационих технологија довело је до крупних промена у традиционалном војном образовању. Једна од тих промена односи се на коришћење озбиљних игара при симулацији реалног војног окружења. Овај прегледни рад пружа неколико дефиниција, поделу озбиљних игара, као и разлику између озбиљних игара и игара намењених забави. Осим тога, у раду се разматрају војне апликације код обуке, система за симулацију и у образовању.

Кључне речи: озбиљне игре, видео-игре, војно образовање, симулација.

Paper received on / Дата получения работы / Датум пријема чланка: 26.01.2018. Manuscript corrections submitted on / Дата получения исправленной версии работы / Датум достављања исправки рукописа: 06.03.2018.

Paper accepted for publishing on / Дата окончательного согласования работы / Датум коначног прихватања чланка за објављивање: 08.03.2018.

(c) 2018 The Author. Published by Vojnotehnički glasnik / Military Technical Courier

(www.vtg.mod.gov.rs, Втг.мо.упр.срб). This article is an open access article distributed under the terms and conditions of the Creative Commons Attribution license

(http://creativecommons.org/licenses/by/3.0/rs/).

() 2018 Автор. Опубликовано в «Военно-технический вестник / Vojnotehnički glasnik / Military Technical Courier» (www.vtg.mod.gov.rs, втг.мо.упр.срб). Данная статья в открытом доступе и распространяется в соответствии с лицензией «Creative Commons»

(http://creativecommons.org/licenses/by/3.0/rs/).

(c) 2018 Аутор. Објавио Војнотехнички гласник / Vojnotehnički glasnik / Military Technical Courier (www.vtg.mod.gov.rs, втг.мо.упр.срб). Ово је чланак отвореног приступа и дистрибуира се у складу са Creative Commons licencom (http://creativecommons.org/licenses/by/3.0/rs/). 